U. S. NATIONAL MUSEUM
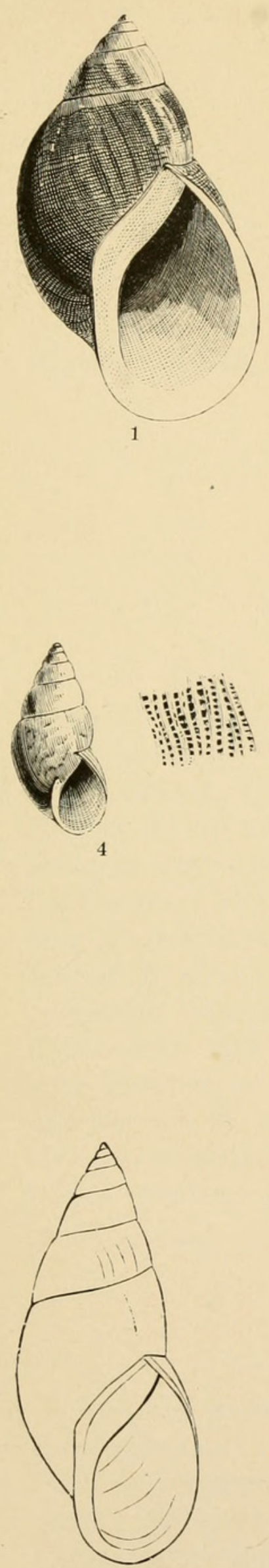

๘
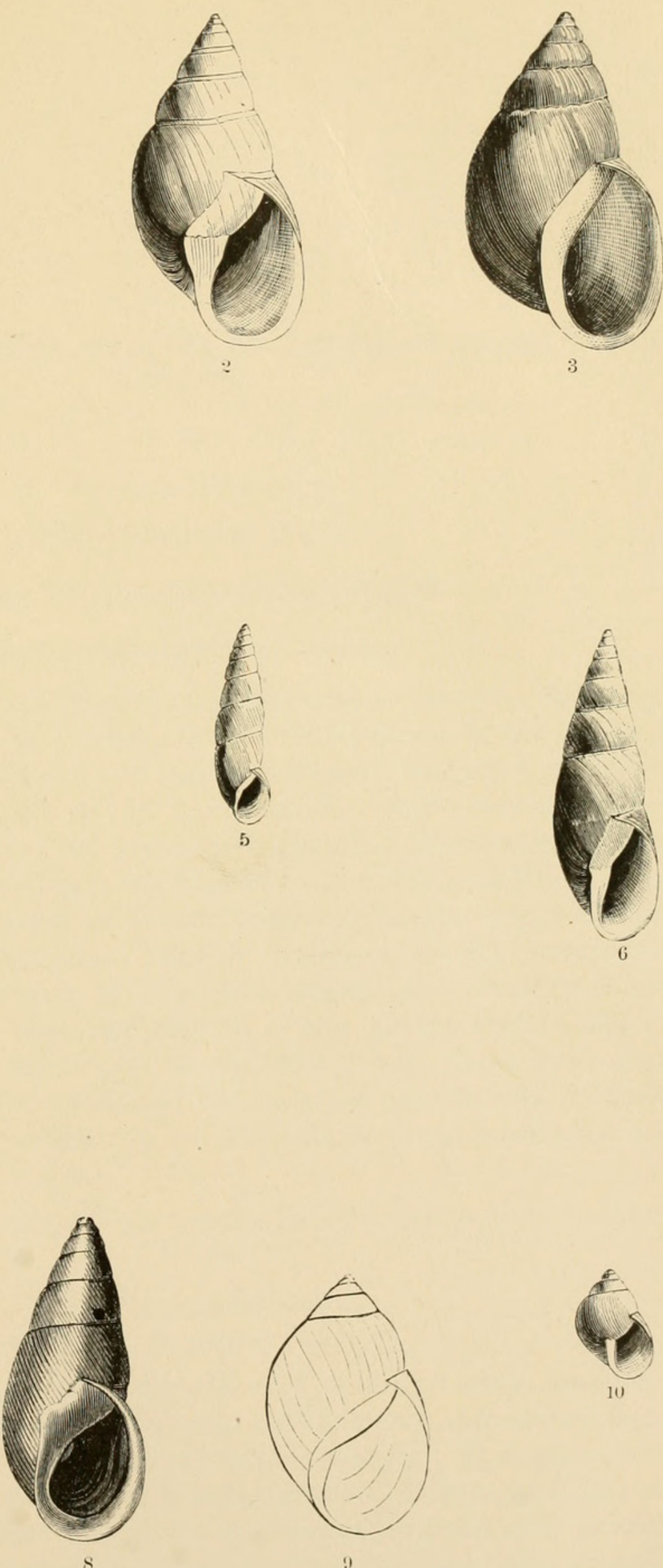

Lower Californian Bulimulus. 



\section{DESCRIPTIONS OF NEW SPECIES OF AMERICAN FRESH-WATER CRABS.}

BY

Mary J. Rathbun.

(With Plates LxxIII-LxxviI.)

\section{Family PSEUDOTHELPHUSID $\AA$.}

\section{PSEUDOTHELPHUSA Saussure.}

The synonymy of this American genus with a complete list of spe cies is given by Prof. S. I. Smith in the Transactions of the Connecticut Academy, Vol. II, 1870. In the Annals and Magazine of Natural History (6) III, p. 7, 1889, Mr. R. I. Pocock describes a new species ( $P$. temuipes) from Dominica, and gives distinguishing characteristics of all the species. The collection of the United States National Museura contains no described species of Pseudothelphusa, but the genus is represented by eight new species. They all possess a cervical suture, two epigastric lobes separated by a median suture, two small $\mathrm{Y}$-shaped depressions near the posterior margin of the gastric region, and five rows of spines on the dactyls of the ambulatory legs, three rows above and two below. The exognath of the external maxillipeds is shorter than the ischium of the endognath. The species are grouped according to the character of the front.

$A^{\prime}$. Front not vertically deflexed, but rounding smoothly downward to the inferior * margin.

Pseudothelphusa jouyi.

(Pl. LxxıII ; Pl. Lxxıv, Figs. 1-3.)

Carapace convex, punctate, smooth, and shining, much broader in the male than in the female. Cervical suture short and curved, sometimes not continued to the antero-lateral margin. Epigastric lobes faintly indicated by a short horizontal groove in front of them, of a lighter color; sometimes the groove is obsolete, but the color remains. There is no trace of a superior frontal crest, the front rounding smoothly down to the margin, which is not visible from above and is strongly retreating at the center. Median sulcus shallow, dividing the front 
into two lobes. Seen from in front, the margin is nearly horizontal; seen from below, the two lobes are slightly arched forward. There is no outer orbital fissure. The frontal and upper orbital margins are indistinctly ridged, and are granulate in small specimens; in large ones the ridge is uneven, the normal granulation being feebly indicated. Lower orbital margin granulate. Antero-lateral margins finely denticulate, the denticles obsolete in adult males, where the margin is simply uneven. Ischium of maxillipeds elongate, merus subtriangular, endognath but slightly overlapping the jugal area; exognath shorter than the ischium (Pl. Lxxiv, Fig. 3). The inferior surface of the body is punctate, the punctæ being larger next the orbit. The cervical suture is present on the lower surface. The abdomen of the male (Fig. 1) is widest at the distal end of the third and the proximal end of the fourth segment; lateral margins of third and fourth segments convex, of fifth concave. Extremity of appendage of first segment with lateral expansions above, the outer one larger and with a single sharp tooth pointing outward and downward, the inner one with a spatulate tooth pointing forward and inward (Fig. 2). The abdomen of the female conceals the sternum. Chelipeds very unequal. Merus with short, stout spines on the inner margin; upper margin with dentiform tubercles on the proximal two-thirds; lower outer margin rounded, with a few granules; a line of granules on the inner surface near the carpus. Carpus punctate, with a short, broad longitudinal groove above and a stout inner spine. Larger hand in male much inflated, punctate, smooth; fingers widely gaping, with strong teeth. Smaller hand with margins subparallel, fingers almost meeting: when closed. In the females the chelipeds are more nearly equal, and in character resemble the smaller cheliped of the male. Ambulatory legs little compressed; merus slender, with upper and lower margins subparallel, upper margin blunt, with depressed spinules, which become obsolete in adults; carpus feebly spinulous above; propodus, above and below.

Color, a rich reddish brown.

Length of $\delta 27^{\mathrm{mm}}$; width, 43.5 ; length of large ehcliped, 86 . Length of 729 ; width, 46 ; length of large cheliped, 66 .

Many specimens were collected by Mr. P. L. Jouy in 1892 at the following localities in Mexico:

Lake Chapala, about 5,000 feet elevation, among stones and shingle on lake shore; February 19, 7 s, 80 ₹, mostly with eggs (17718); Febi uary 20, 7 \& , 2 ₹ , 4 young, all small (17719).

Juanacatlan, Falls of Rio San Juan, between Lake Chapala and Guadalajara, April 26; 6 o , 11 ₹, mostly small (17720).

Prof. A. Dugès has presented specimens from Valle de Santiago, State of Guanajuato; 1 $\hat{\delta}, 1>$ (17721); also an additional female (4122) from the same State, probably from the same locality.

This species bears a strong resemblance to $P$. americana Saussure from Hayti, but that species is without a cervical suture. 


\section{Pseudothelphusa dugesi.}

(Pl. Lxxiv, Figs. 4 and 5.)

This species is so closely related to jouyi that one might easily confound the two. It can be distinguished, however, first, by the front which is sinuous and slightly bilobed, more abruptly deflexed than in jouyi, with a strong marginal ridge visible from above and defined by a submarginal groove; viewed from in front the margin is nearly straight; second, by the more compressed meral joints of the ambulatory legs, which are slightly dilated in the middle, the upper edge thin; third, by the appendages of the first segment of the male abdomen, in which the inner tooth at the extremity is more slender than in jouyi and is directed closer to the appendage.

Color, dark olive-brown.

Length of male 21 ; width, 33 ; length of cheliped about $53^{\mathrm{mm}}$. Length of female, 20; width, 33.5; length of large cheliped, about 43.

Cuernavaca, State of Morelos, Mexico, P. L. Jouy, August, 1892; 7 oิ, 1 ? (17722).

A small female from the State of Guanajuato (?), A. Dugès (4389), has the meral joints of the ambulatory legs proportionally wider than in the specimens from Cuernavaca, all of which are much larger.

\section{Pseudothelphusa terrestris.}

(Pl. Lxxiv, Figs. 6 and 7.)

This species much resembles jouyi and dugesi, but the carapace is wider, the cervical suture deeper and more conspicuous, the gastric region more elevated. Front not rounding downward as in jouyi but abruptly deflexed as in dugesi, the margin strongly ridged, defined by a well-marked submarginal groove, and visible from above. Viewed from in front the two halves of the margin slope downward toward the center. The outer orbital angle is less advanced than in jouyi. The denticles of the antero-lateral margins are less prominent than in specimens of jouyi of equal size, the obliteration in adults being even more complete in this species. In the abdomen of the male the terminal segment is more acute than in jouyi; the appendage of the first segment differs in having at the tip on the outer side a much narrower lateral expansion with a narrower, sharper tooth, and on the inner side, a somewhat scythe-shaped tooth. Chelipeds similar to those of jouyi; the lower outer margin of the merus has a distinct line of granules. The am bulatory legs are more compressed, the merus joints thin above. and wide in the center.

Color, olive-brown.

Length of $\delta$ 21; width, 36 ; length of large cheliped, about $59^{\mathrm{mm}}$. Length of $q 19$; width, 32 ; length of large cheliped, about 33 . In this female specimen the chelipeds are almost equal.

Collected by Mr. P. L. Jouy at A tamajac, 3 miles west of Guadalajara, April, 15, 1892, 3 o , 2 ㅇ (17723); also at Barranca Ibarra, near Guada- 
lajara, April 20-22, 1892, under stones on moist hillside, about 10 feet above the river, 3,700 feet above sea level, and 1,500 feet below Guadalajara, 8 os, $s$ $q$, small (17724).

$\mathrm{A}^{\prime \prime}$. Front vertically deflexed, forming a blunt crest.

$\mathrm{B}^{\prime}$. Crest smooth.

\section{Pseudothelphusa verticalis.}

(Pl. Lxxiv, Figs. 8 and 9.)

Carapace flattened, obscurely punctate. Cervical suture deep and short, continued to the margin. Epigastric lobes depressed. Front vertically deflexed; superior margin not ridged or granulate, but presenting a smooth, rounded surface, which is almost straight and scarcely interrupted by the shallow median sulcus. Infero-frontal margin with a prominent ridge, indistinctly granulate, a submarginal groove, and a shallow median sinus. The ridge is continuous with the orbital margin. Antero-lateral margins denticulate. Orbits deeper than in jouyi, sometimes with a shallow hiatus. In the male abdomen the appendages of the first segment are very different from those of the species above described (Fig. 9). Chelipeds with the merus triangulate, broadening distally, shorter than in jouyi; upper margin with dentiform tubercles, which become almost obsolete toward the carpus; lower inner margin with two irregular rows of spiny teeth; lower surface with a line of granules on the outer and distal margins; carpus shorter than in jouyi; large hand very deep and swollen, much larger than the small hand; fingers gaping in the larger cheliped. The ambulatory legs are compressed, broad; merus joints much dilated, with a thin upper margin, obscurely denticulate.

Length of 825 ; width, 42 ; length of large cheliped $72^{\mathrm{mm}}$.

Length of $\& 22.8$; width, 39 ; length of large cheliped $54^{\mathrm{mm}}$.

Tehuantepec, Mexico, Dr. Spear; 4 s, 5 \& (2537).

$\mathrm{B}^{\prime \prime}$. Crest tuberculate.

\section{Pseudothelphusa xantusi.}

Carapace in shape resembling the preceding, slightly convex, punctate, granulate anteriorly and laterally. There is a trace of an additional suture behind the cervical suture, which is not an even curve, but turus slightly toward the horizontal near the margin. Epigastric lobes well-marked, tuberculate, separated by a deep, narrow median sulcus, which divides the superior frontal crest. This erest is blunt, and is provided with a wide row of tubercles, and near the orbit turns backward, following the line of the orbit for a short distance. Inferior frontal margin with a prominent ridge, which projects forward, is somewhat bilobed, granulate, and visible from above. Orbits large, not filled by the eyes; margin granulate except for a short distance beneath the outer angle, where the absence of granules simulates a shallow fissure. Antero-lateral margin denticulate, slightly interrupted 
at the cervical suture and between that suture and the orbital angle. Merus of maxilliped more quadrate, less triangular than in the preceding species. Inferior regions of the carapace very finely granulate and punctate, cervical suture present. Jugal area pubescent as far back as the sternum. Small cheliped (the only one present) granulate, punctate, with a broad merus; inner face outlined below and distaliy with bead-like tubercles, inner margin with a double row of blunt spines, increasing in size distally, upper margin with spinulous rugæ extending on the outer surface distally. Carpus with a very shallow sulcus, a short inner spine; inner margin spinulous. Upper and lower margins of hand subparallel; fingers in contact. The merus joints of the ambulatory legs are flattened, widening toward the center, denticulate above; carpal and propodal joints spinulous on the upper, inner, and distal margins.

Length, about 29 ; width, 49 ; length of smaller cheliped, about $61^{\mathrm{mm}}$.

? Mexico, John Xantus; a single mutilated specimen, $q$ (2527).

This specimen is labeled "Cape St. Lucas", but it is more likely to have come from the vicinity of Manzanillo or Colima, where Mr. Xantus made valuable collections of fresh-water fishes and mollusks in 1862 .

$A^{\prime \prime \prime}$. Front vertically deflexed, forming an acute lamellate crest.

\section{Pseudothelphusa colombianus.}

(Pl. Lxxrv, Fig. 10; Pl. Lxxv, Fig. 1.)

Carapace slightly convex, finely punctate, granulate anteriorly and near the lateral margins, the granules more evident in the smaller specimen. Epigastric lobes very prominent, the ridge continued faintly for a short distance in a transverse line of granules. Cervical suture curved, becoming less marked near the lateral margin. Superior frontal margin lamellate, almost straight, tuberculate, divided by a $V$ shaped notch at the extremity of the median sulcus. The margin near the orbit turns nearly parallel to the orbital margin and terminates just above the base of the eye. Inferior frontal margin slightly in advance of the superior, sinuous, with a prominent, horizontal, ridged, and granulate margin, which is continuous with the tuberculate or crenulate orbital margin. Front deepest at the outer ends. Antero-lateral margins denticulate, interrupted by a shallow sinus at the cervical suture and another between that and the orbit. External orbital fissure small and shallow, formed by the absence of one or two granules. Inferior surface of the carapace finely granulate near the margin. Jugal region pubescent and anteriorly granulate. Chelipeds of female unequal, punctate. Smaller cheliped much like that of xantusi, but with few granules; the inner margin has a single row of spines, and below it a row of tubercles. Larger cheliped similar to the smaller, except that the propodus is much deeper (Pl. Lxxv, Fig. 1). Fingers in contact when closed. Am. bulatory legs little compressed; meral joints widening toward proximal end, denticulate on upper margin, and in the last pair prominently ridged 
on lower outer margin; earpal joints spinulous above and distally; propodal joints with small spines above, below, and distally.

Length, 28.5; width, 50; length of cheliped, about $65^{\mathrm{mm}}$.

River David, Chiriqui, United States of Colombia, about latitude $8^{\circ}$ $28^{\prime} \mathrm{N}$, longitude $82^{\circ} 24^{\prime} \mathrm{W}$., at an elevation of 4,000 feet above the sea; "very rapid streams descending from Mount Chiriqui"; J.A.McNiel, July, $1883 ; 29(5512)$. In the same bottle there is an ambulatory leg of a specimen one-half again as large, which is apparently the same species.

\section{Pseudothelphusa lamellifrons.}

\section{(Pl. LXXv, Figs. 2-5.)}

The carapace of this species is allied to that of colombianus; the granules of the anterior and lateral portions are, however, more prominent, and the cervical suture is supplemented by another shorter parallel suture a little posterior to the first, but not prolonged to the margin. Front similar to that of colombianus, but narrower and deeper." External orbital fissure very shallow and broad, with a denticle in the middle. Antero-lateral margin very thin and acute, with fine teeth a little more prominent than in colombianus and crowded close together. Ischium of maxilliped broadening noticeably at the distal end. Abdomen of male contracted at the fifth segment (Fig. 4); the extremity of the appendage of the first segment is laminate, and folded and compressed laterally, the inner side having two lobes above, the posterior one very large, and the outer side with a blunt tooth pointing forward and outward (Fig. 5). Chelipeds in shape and armature resembling those of colombianus, but the granules are prominent; the upper and lower margins of the basal portion of the larger propodus more acurate than in those of the female of that species. Fingers in contact. The meral joints of the ambulatory legs are compressed, very wide at the center, the upper edge thin.

Length, 22; width, 34.3 ; length of cheliped about $46^{\mathrm{mm}}$.

Isthmus of Tehuantepec, Mexico, F. E. Sumichrast; 3 males (3289).

\section{Pseudothelphusa richmondi.}

\section{(Pl. Lxxv, Figs. 6-10.)}

Carapace more convex than in the two preceding species, finely punctate, with scaly granules near the lateral margin. Cervical suture deep and almost straight. Epigastric lobes well marked. Median sulcus short, making a V-shaped noteh in the superior frontal margin. There are three faint depressed tubercles arranged transversely across the gastric region. Margins of front and orbits crenulate or granulate. Superior frontal margin nearly straight, as seen from above, but seen from in front, the two sides slope downward to the median line; the outer extremities join the orbital margin. Inferior 
margin sinuous, its lobes visible from above (Fig. 6). The external orbital tooth and the next lateral tooth are finely dentate; posterior to the cervical suture there are ten small spiniform teeth nearly equal in size, followed by a diminishing series of spinules on the postero-lateral margin; the first of the ten teeth has, on one side of the carapace, one, on the other side two, accessory spinules. Orbital fissure broad, shallow, U-shaped. Inferior surface of the carapace granulate near the lateral margin, and granulate and pubescent on the jugal area. Maxillipeds broad, considerably overlapping the jugal area; ischium much wider at the distal than at the proximal end; merus more quadrate than in preceding species. Last two segments of the male abdomen longer and narrower than in lamellifrons (Fig. 7); appendages of first segment with superior portion of the extremity armed with three unequal spines, the inferior portion having a concave oval area. Chelipeds unequal, punctate, with scaly granules, which form rugosities on the outer surface of the merus; merus and carpus armed similarly to those of colombianus, except that there is not a continuous line of granules near the upper margin of the inner surface. Hands rough, with scaly granules, especially on the margins. Large hand deep, lower margin very convex. Fingers in contact. Meral joints of ambulatory legs compressed and widening toward the center; upper margins of meral, carpal, and propodal joints, and lower margin of propodal joints spinulous; dactyls very slender.

Length, 32.5; width without spines, 49 ; length of cheliped about $70^{\mathrm{mm}}$.

Found on dry land near a small creek which flows into the Escondido River, 50 miles from Bluefields, Nicaragua, by Mr. Charles W. Richmond, October 30, 1892; one male (17725).

\section{POTAMOCARCINUS.}

Established by Milne Edwards* for a species (P. armatus) which differs from Pseudothelphusa in having the superior frontal crest sharp and lamellate, and more prominent than the inferior, the carapace armed with strong spines and an external orbital hiatus.

This genus is doubtfully distinet from Pseudothelphusa, some species of which have an orbital hiatus; in P. richmondi the front is sharp and lamellate, though not entirely concealing the inferior crest. In Pseudothelphusa can be seen every gradation between the sharp-crested front and the smooth front without a ridge. There seems to be no external character to distinguish Potamocarcinus except the strong marginal teeth, which is hardly a generic character. The following species is therefore placed provisionally in this genus.

${ }^{*}$ Ann. Sei. Nat. (3), xx, p. 208, 1853. 
Potamocarcinus nicaraguensis.

(Pl. Lxxvi; Pl. LxxviI, Figs. 1-3.)

Potamocarcinus armatus Stimpson (not Milne Edwards), Proc. Acad. Nat. Sci. Phila. x, p. 100, 1858.

Stimpson, in his unpublished report on the Crustacea collected by the North Pacific Exploring Expedition, says of P.armatus, "We have but one specimen of this species, a small male, half an inch in length. It differs somewhat from the large female described by Milne Edwards, in that the carapace is punctated, and, toward the lateral margins, somewhat granulated. The second and third antero-lateral teeth are bifid. Dactyli scarcely quadrangular, almost rounded, also smaller and less spinulose. It was found at Omotepec Island in Lake Nicaragua, by Mr. Charles Wright, botanist of the expedition."

Potamocarcinus nicaraguensis is a large species; small specimens agree with Stimpson's diagnosis, except that the dactyls are not less spinulous than in Milne Edwards's figure of armatus.

Carapace broader anteriorly than in armatus, slightly convex, distinctly marked with small puncte, granulate near the lateral margins, the granules most prominent in young specimens. Cervical sulcus deep and curved; there are wide and deep grooves either side of the posterior gastric area, and small $Y$-shaped grooves between them. The epigastric lobes are well marked, divided by a narrow sulcus leading to the front. Superior frontal margin horizontal, granulate, more advanced in the central portion; median fissure $\mathrm{V}$-shaped. Front concave, the inferior margin much behind the superior, the two halves separately arched upward. Postorbital tooth obtuse, outer margin rounded. Second tooth broader, obtuse, often with one or more accessory teeth on its margins. Third tooth, that directly posterior to the cervical suture, broad, very variable in shape, but always bilobed. Remaining large teeth, four to six in number, irregular in shape and position, acute, spinous. There are often small intervening teeth. Postero-lateral margin with several spinules which decrease in size from the lateral angle. External orbital hiatus deep and wide; orbital margin granulate. Lower surface of the carapace granulate near the lateral margin and on the jugal area. The margin of the epistome is three-spined; median spine long and curved upward. As in armata, the endognath of the external maxillipeds is very wide and covers a portion of the jugal region; the exognath is much shorter than in armata, never exceeding one-half the length of the ischium. The appendages of the first segment of the male abdomen are very stout, and at the summit present a concave outer surface which has a spine at the antero-inferior angle, a lobe at the antero-superior and posteroinferior angles, and two spines at the postero-superior angle (Pl. Lxxvi, 
Fig. 3). Abdomen of female very large, concealing the sternum. Chelipeds long and strong, unequal, punctate; merus roughened above, inner margin spinous, the spines longer and stronger at the distal end; inferior margin granulate. Carpus with a very shallow median groove near the center, and a stout spine on the inner margin. Large hand much swollen, deep; there is a short line of tubercles on the inner side of the lower margin near the carpus; dactyl strongly arched; fingers and lower surface of hand speckled with small dark spots, which, on the fingers, are granulous; teeth of prehensile edges irregular, broad, and strong. Smaller hand less broad and deep; fingers in contact or slightly gaping; otherwise as in the larger hand. The chelipeds of the female are shorter and more slender than those of the male. The merus joints of the ambulatory legs are slightly compressed; upper and lower margins almost parallel; upper margin obscurely granulate; carpal joints unarmed; propodal joints spinulous on the distal portion; dactyli compressed, with five rows of spines.

Length of $857^{\mathrm{mm}}$; width without spines, 85 ; approximate length of larger cheliped, 158; length of propodus, 90; depth, 37; thickness, 23. Length of $\%, 63$; width, without spines, 95; approximate length of larger cheliped, 135 ; length of propodus, 71 ; depth, 25; thickness, 15.

Lake Nicaragua, Dr. J. F. Bransford ; 4 ô, 2 o (5837), grading in size from two inches to three-fourths of an inch in length.

Near Greytown, Nicaragua, Dr. Louis F. H. Birt; 2 s , 3 q (13788) all large. Greytown is at the mouth of the river San Juan, an outlet of Lake Nicaragua.

Rio Frio, Costa Rica, a tributary of the San Juan, Charles W. Richmond, March 3,1892; one ㅇ (17957).

\section{EPILOBOCERA Stimpson.}

In 1860 Stimpson instituted the genus Epilobocera (Ann. Lyc. Nat. Hist. N. Y., VII, p. 234) for a fresh-water crab of the family Thelphuside, distinguished by the frontal process meeting the internal suborbital lobe, behind which the antenna passes to the orbital cavity. The merus of the external maxilliped is transverse, its anterior margin rounded, and the palpus goniarthroid. The type species, E. cubensis, was found in fresh-water streams near Santiago, Cuba.

In 1870 Prof. S. I. Smith (Trans. Conn. Acad. II, p. 150) gives a more detailed description of E. cubensis, and describes another species, E. armata, probably from the Bahamas. The generic diagnosis should be amended so as to include species in which the frontal process nearly joins the suborbital-lobe, the character being at best of doubtful value. The following distinguishing characters may be added: A process projects from the upper side of the expiratory canal, and the exognath of the external maxillipeds overreaches the ischium of the endognath.

Proc. N. M. $93-42$ 
SYNOPSIS OF SPECIES.

A Superior frontal crest projecting beyond the inferior.

B' Carapace granulated near the margins above and below ............... CubENsis.

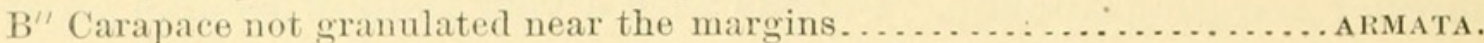

$A^{\prime \prime}$ Superior frontal crest not projecting beyond the inferior.

$B^{\prime}$ Carapace with coarse sealy granules near the margins alove and

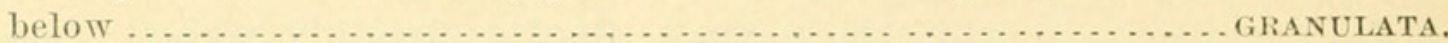

B" Carapace without coarse scaly granules near the margins ......... HAYTENsis.

\section{Epilobocera haytensis.}

(Pl. LXXVII, Figs. 4 and 5.)

Carapace very slightly convex, finely granulate, and punctate. Cervical sulcus deep. Cardiac region with shallow depressions on either side, and two minute $Y$-shaped grooves in the sulcus between the gastric and cardiac regions. Epigastric lobes distinct, separated by a well-marked sulcus, which extends forward and forms a wide median sinus in the superior frontal margin. This margin is prominent and nearly straight when seen from above, but slopes downward toward the middle, and in the larger specimen the two halves are inclined slightly backward toward the meaian line. The margin is unevenly tuberculate, and near the orbital border it is directed backward and ends above the base of the eye. The inferior margin of the front is three-lobed, the median lobe directed downward and forward, the lateral lobes rounded and horizontal, projecting well beyond the superior margin. The margin is crenulate, and also the orbital border, which is continuous with it. There is a broad hiatus beneath the outer angle of the orbit. The internal suborbital lobe is very broad and concave, and nearly, but not quite, touches the subfrontal process. The antero-lateral margin is marked by small blunt teeth, irregular in size and shape, and interrupted by a wide sinus at the cervical suture, and another near the external orbital angle. The teeth become smaller and more indistinct near the postero-lateral margin, which is slightly concave, smooth, and rounded. The marginal teeth are less plainly marked in the smaller specimen. Labial border of the epistome with three lobes; median lobe acute, projecting downward and slightly forward; lateral lobes shorter, less acute, their inner margins arched upward and forward. The margins of the lobes are tuberculate. On the lower side of the carapace there is a line of tubercles following the cervical suture, and the anterior portion of the jugal area is tuberculate. The endognaths of the external maxillipeds in width do not exceed the buccal eavity; the merus is more or less quadrate, the antero-external angle rounded (Fig. 5). The male abdomen is widest at the third segment, and does not taper regularly to the last, but the margins of the fourth, fifth, and sixth segments are separately convex. The appendages of the first segment are bent outwards at almost a right angle near the extremities, which are lobed and spinuliferous. Chelipeds unequal. The merus is armed with stout 
blunt spines on the inner margin, irregularly dentate on the upper margin, scabrous on the upper portion of the outer surface, and with a line of small tubercles on the lower outer margin; carpus faintly scabrous near the merus, with a strong, blunt spine at the inner angle. Hand inflated; fingers irregularly dentate within, gaping to the tips in the male, in contact in the female. Ambulatory legs flattened, sparingly pubescent; merus joints denticulate above; carpal joints indistinetly denticulate above, with a few spinules on the distal margin; propodal joints with two rows of spines above and below, the lower ones the longer, and one row on the distal margin; dactyls with three rows above and two below, with fewer spines in the lower rows.

Length of larger specimen, a female, $46^{\mathrm{mm}}$; width, 76 . Length of of 21.5 ; width, 38 .

Hayti; A. G. Younglese; $q$ (3216). San Domingo; W. M. Gabb, 1878; के (3192).

\section{Epilobocera granulata.}

(Pl. LxxviI, Fig. 6.)

The specimens are smaller than in the preceding species, and are sexually immature. The species is closely allied to haytensis. The areolations of the carapace are the same. The anterior portion is more distinctly granulous, especially the epigastric lobes, and the branchial regions are coarsely granulate near the margins. The antero-lateral margin is not interrupted at the cervical suture, but there is a deep sinus next the postorbital tooth, and the first tooth following is very small. The next 6 to 9 teeth are larger and more regular than the remainder. Superior frontal border as in haytensis. The inferior frontal border is thin, more advanced than the superior, and in a front view the two halves are seen to arch upward. The external suborbital fissure is very shallow, scarcely more than an interruption of the denticles of the orbital border. The subhepatic and subbranchial regions are granulate, and the cervical ridge is present as in haytensis, but the jugal area is smooth, except at the anterior extremity. The epistome has three acute lobes, tuberculate on the margins, similar to those of haytensis. The maxillipeds in width exceed the buccal cavity; the merus has the antero-external angle much more arcuate than in haytensis (Fig. 6). Abdomen of male narrower than in haytensis, especially noticeable in the penultimate segment. The merus and carpus of the chelipeds of the male are similar to those in haytensis; the carpal spine is sharper. Hands little dilated; fingers very slightly gaping at their base. Ambulatory legs sparingly pubescent, with meral joints denticulate above; carpal, propodal, and terminal joints armed as in haytensis.

Length, 13.5; width, 23 millimeters.

West Indies (6705). Four specimens, all more or less mutilated. Two of them are males, and probably also the other two, 


\section{$2 \mathrm{BHL}$ Biodiversity Heritage Library}

Rathbun, Mary Jane. 1893. "Descriptions of new species of American fresh-water crabs." Proceedings of the United States National Museum 16(959), 649-661. https://doi.org/10.5479/si.00963801.16-959.649.

View This Item Online: https://www.biodiversitylibrary.org/item/53716

DOI: https://doi.org/10.5479/si.00963801.16-959.649

Permalink: https://www.biodiversitylibrary.org/partpdf/53067

\section{Holding Institution}

Smithsonian Libraries

\section{Sponsored by}

Smithsonian

\section{Copyright \& Reuse}

Copyright Status: Public domain. The BHL considers that this work is no longer under copyright protection.

This document was created from content at the Biodiversity Heritage Library, the world's largest open access digital library for biodiversity literature and archives. Visit BHL at https://www.biodiversitylibrary.org. 